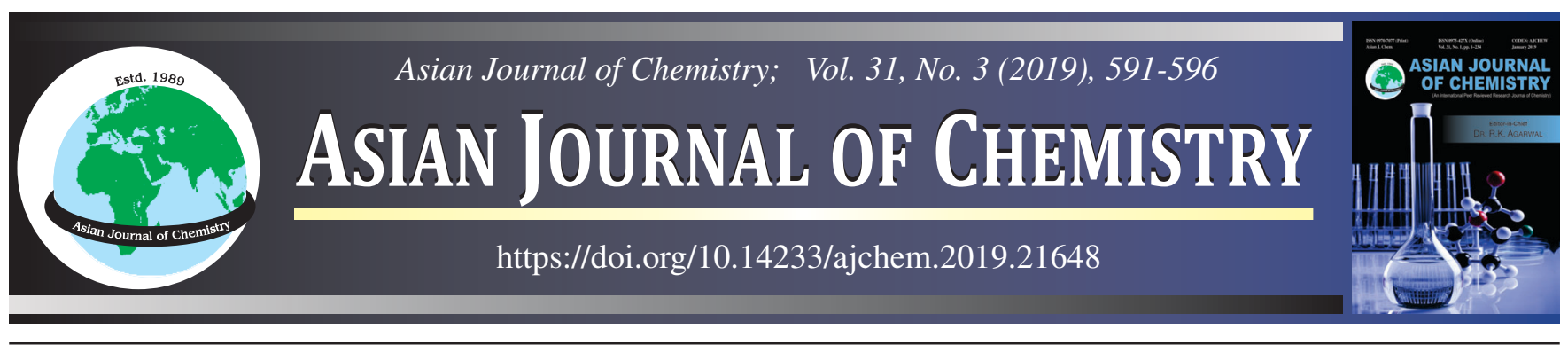

\title{
Synthesis, Spectroscopic, Thermal and X-Ray Structure of Aminoguanidinium and Hydrazinium Uranyl Trichloroacetates
}

\author{
T.M. Ahamed Hussain and B.N. SivaSANKaR*
}

Department of Chemistry, Government Arts College, Udhagamandalam-643002, India

*Corresponding author: E-mail: sivabickol@yahoo.com

Received: 13 August 2018; Accepted: 31 October 2018;

Published online: 31 January 2019;

AJC-19251

\begin{abstract}
New aminoguanidinium and hydrazinium uranyl complexes of trichloroacetate with formulae $\mathrm{H}_{2}(\mathrm{HAgun})_{2}\left[\mathrm{UO}_{2}\left(\mathrm{Cl}_{3} \mathrm{COO}\right)_{5}\right]\left(\mathrm{NO}_{3}\right)(\mathbf{1})$ and $\left(\mathrm{N}_{2} \mathrm{H}_{5}\right)\left[\mathrm{UO}_{2}\left(\mathrm{Cl}_{3} \mathrm{COO}\right)_{3}\right]$ (2) where HAgun is aminoguanidinium cation have been prepared in aqueous media and charaterized by analytical, spectral, thermal and X-ray crystallographic studies. The electronic spectra of the complexes confirm the presence of uranyl cation in the molecules. The infrared spectra of the complexes show the N-N stretching frequency of aminoguanidinium in the range of $1100 \mathrm{~cm}^{-1}$ and for hydrazinium in the range of $970 \mathrm{~cm}^{-1}$ conforming their ionic nature. The simultaneous TG-DTA of both the complexes show two step degradation to yield $\mathrm{U}_{3} \mathrm{O}_{8}$ as the final residue which was confirmed by X-ray powder diffraction. The structural morphology of $\mathrm{U}_{3} \mathrm{O}_{8}$ has been studied by SEM technique. The crystal structure of compound $\mathbf{1}$ reveals seven coordination around uranium with pentagonal bipyramidal geometry. Aminoguanidinium cations and nitrate anion are present outside the coordination sphere as charge compensating species. However, for hydrazine complex hexagonal bipyramidal geometry has been assigned on the basis of analytical and spectral studies.
\end{abstract}

Keywords: Aminoguanidinium cation, Hydrazinium cation, Uranyl ion, X-ray crystal structure, Thermal analysis.

\section{INTRODUCTION}

The chemistry of uranyl complexes dominated by uranyl dication has received remarkable attention over the years and has found a variety of application as molecular receptors in the area of supramolecular chemistry and coordination chemistry [1-3]. Uranyl dication $\mathrm{UO}_{2}{ }^{2+}$ has a strong covalent character of axial $\mathrm{U}=\mathrm{O}$ bond making its coordination chemistry quite exclusively limited in the equatorial plane. Moreover, uranyl dication is essentially a linear $\mathrm{O}=\mathrm{U}=\mathrm{O}$ species due to repulsion from its oxygen atom forcing the coordinating ligand nearly into a plane perpendicular to the axis of ion [4-11]. Furthermore, it is surrounded by 4-6 donor atoms at equatorial position and exists in octahedral, pentagonal bipyramidal or hexagonal bipyramidal coordination environment [12].

A great variety of compounds are formed between monocarboxylic acid and uranyl cation. The most characterized type being the tricarboxylates. Hydrazinium uranyl tricarboxylates such as $\mathrm{N}_{2} \mathrm{H}_{5} \mathrm{UO}_{2}(\mathrm{RCOO})_{3}$ where $\mathrm{R}=\mathrm{CH}_{3}, \mathrm{CH}_{2} \mathrm{CH}_{3}$ or $\mathrm{CH}_{2}=\mathrm{SH}$ have been prepared and crystal structure of $\mathrm{N}_{2} \mathrm{H}_{5} \mathrm{UO}_{2}\left(\mathrm{C}_{2} \mathrm{H}_{5} \mathrm{COO}\right)_{3}$ has been determined [13]. No reports are available on aminoguanidinium uranyl complexes of carboxylic anions. Trichloro acetic acid is a strong acid due to electron withdrawing nature of chlorine atoms hence expected to form metal complexes much easier than acetic acid and other monocarboxylic acids. The hydrazinium and aminoguanidinium complexes of uranyl cation with trichloroacetic acid have not been reported so far. The substitution in both acid and hydrazinium greatly influences the geometry of such complexes. In the present investigation, we report the synthesis, characterization and thermal degradation of hydrazinium trichloroacetato uranate and aminoguanidinium trichloroacetato uranate nitrate. We also report the crystal and molecular structure of aminoguanidinium complex.

\section{EXPERIMENTAL}

All the chemicals and solvents were purchased from S.D. Fine Chemicals, Mumbai, India. The solvents were distilled before use and double distilled water was used for the preparation and analyses of the complexes.

This is an open access journal, and articles are distributed under the terms of the Creative Commons Attribution-NonCommercial-ShareAlike 4.0 (CC BY-NC-SA 4.0) International License which allows readers to freely read, download, copy, distribute, print, search, or link to the full texts of its articles and to use them for any other lawful non-commercial purpose as long as the original source is duly acknowledged. 
The hydrazine contents were determined by volumetric analysis using a $0.025 \mathrm{M} \mathrm{KIO}_{3}$ solution under Andrew's condition and uranium(VI) content was determined gravimetrically using oxine $[14,15]$. Elemental analyses $(\mathrm{C}, \mathrm{H}$ and $\mathrm{N})$ were performed using Perkin-Elmer $2400 \mathrm{CHN}$ elemental analyzer. IR spectrum of the complexes were recorded ( $\mathrm{KBr}$ disc) in the range 4000$400 \mathrm{~cm}^{-1}$ on a Bruker alpha spectrophotometer. The simultaneous TG-DTA of the samples in air was recorded using a SWI TG/ DTA 6200 thermal analyzer using about $5 \mathrm{mg}$ of the sample with the heating rate of $10^{\circ} \mathrm{C} / \mathrm{min}$ and platinum cup as sample holder. The X-ray single crystal intensity data were collected on a Enraf -Nonius CAD-4 diffractometer system with graphite monochromated Mo- $\mathrm{K}_{\alpha}$ radiation $(\lambda=0.71073 \mathrm{~nm})$. The structure of aminoguanidinium complex was solved by direct method using SIR 92 program and completed using Fourier techniques and refined by applying full matrix least square techniques. Refinement was carried out using SHELXL-2014 program $[16,17]$. The X-ray powder diffraction pattern was recorded on Philips PW 1050/70 using $\mathrm{CuK}_{\alpha}$ radiation with an iron filter. The measurements were taken in the range of $2 \theta$ angle $20-80^{\circ}$ and wavelength of $1.5406 \AA$. The morphology and microstructure of metal oxide was recorded using a Quanta FEG-250 fieldemission scanning electron microscope (SEM).

Preparation of $\mathrm{H}_{2}(\mathrm{HAgun})_{2}\left[\mathrm{UO}_{2}\left(\mathrm{Cl}_{3} \mathrm{COO}\right)_{5}\right]\left(\mathrm{NO}_{3}\right)(1)$ : The compound was prepared by the addition of an aqueous solution $(30 \mathrm{~mL})$ containing a mixture of aminoguanidine
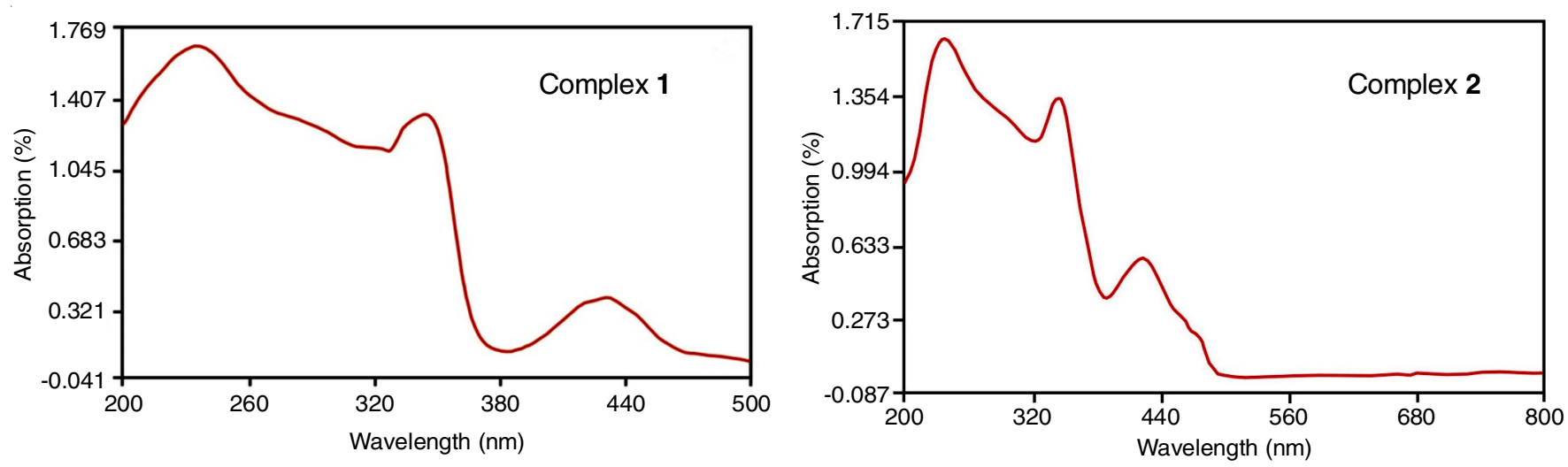

Fig. 1. Electronic spectra of complexes $\mathbf{1}$ and $\mathbf{2}$
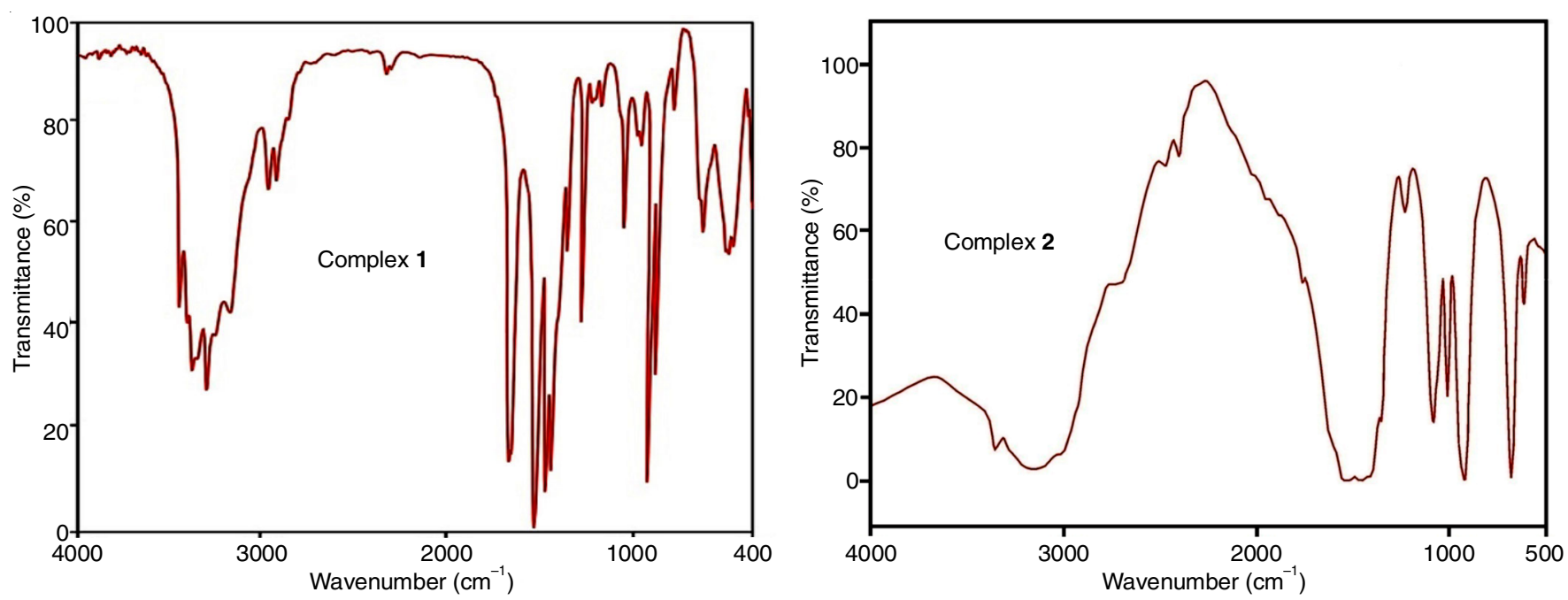

Fig. 2. IR spectra of complexes $\mathbf{1}$ and $\mathbf{2}$ bicarbonate $(4.08 \mathrm{~g}, 0.03 \mathrm{~mol})$ and trichloroacetic acid (4.89 $\mathrm{g}, 0.03 \mathrm{~mol}$ ) to an aqueous solution of uranyl nitrate hexahydrate $(5.02 \mathrm{~g}, 0.01 \mathrm{~mol})$. The resulting clear yellow solution was concentrated to one third of its volume on a water bath and then allowed to stand at room temperature for crystallization. The yellow crystals, suitable for single crystal X-ray studies formed after a weak were separated washed with ice-cold water and air dried.

Preparation of $\left(\mathrm{N}_{2} \mathrm{H}_{5}\right)\left[\mathrm{UO}_{2}\left(\mathrm{COOCCl}_{3}\right)_{3}\right]$ (2): An aqueous solution $(20 \mathrm{~mL})$ containing a mixture of trichloroacetic acid $(4.89 \mathrm{~g}, 0.03 \mathrm{~mol})$ and hydrazine hydrate $(1.5 \mathrm{~mL}, 0.03 \mathrm{~mol})$ was added to an aqueous solution $(30 \mathrm{~mL})$ of $\mathrm{UO}_{2}\left(\mathrm{NO}_{3}\right)_{2} \cdot 6 \mathrm{H}_{2} \mathrm{O}$ $(5.02 \mathrm{~g}, 0.01 \mathrm{~mol})$. The resulting clear yellow solution was concentrated to half of its volume and maintained at room temperature for crystallization. After $48 \mathrm{~h}$, yellow crystalline solid formed was filtered, washed with ice cold water and dried.

\section{RESULTS AND DISCUSSION}

Electronic spectra: The UV-visible spectra of the complexes show (Fig. 1a and 1b) two broad band around 355 and $430 \mathrm{~nm}$, which are attributed to ligand to metal charge transfer LMCT and ${ }^{1} \Sigma \rightarrow{ }^{3} \Pi_{\mathrm{g}}^{+} \mathrm{u}$ transition of uranyl ion respectively [18].

Infrared spectra: The infrared spectrum of complex 1 (Fig. 2a) shows an asymmetric and symmetric stretchings of $\mathrm{O}=\mathrm{U}=\mathrm{O}$ in the regions $920-910$ and $850-830 \mathrm{~cm}^{-1}$, respectively. The asymmetric and symmetric stretching frequencies of carboxylate ions are seen at 1540 and $1410 \mathrm{~cm}^{-1}$, which reveals 

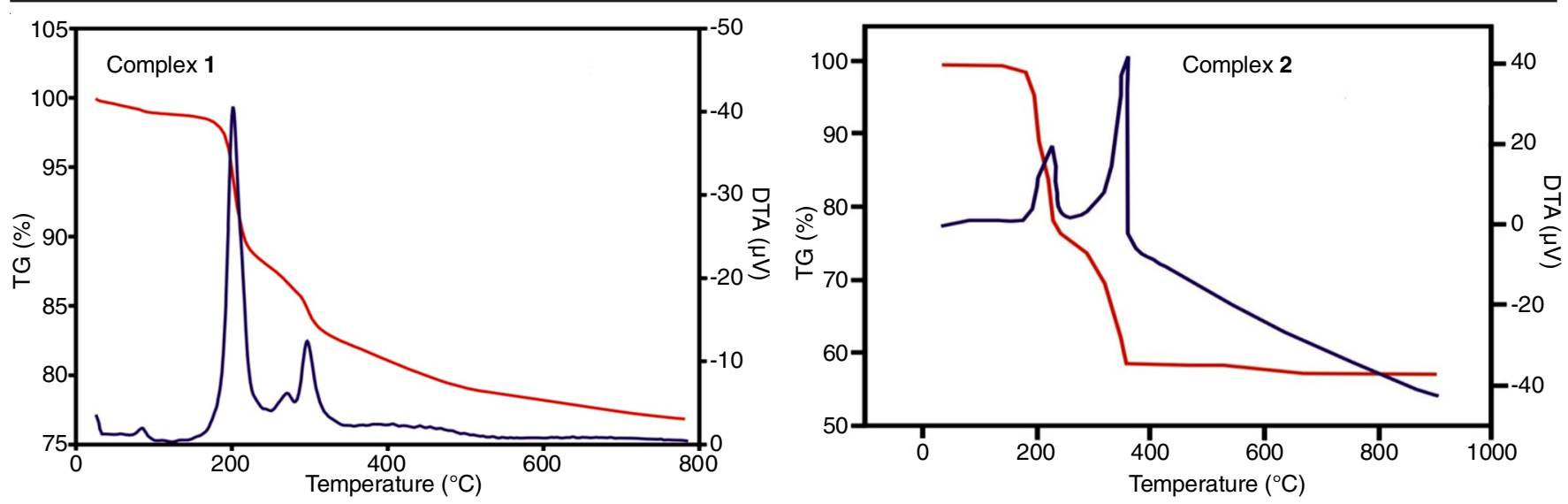

Fig. 3. Simultaneous TG-DTA of complexes 1 and 2

the monodentate coordination behaviour of carboxylate ions. The iminidinium $\mathrm{C}=\mathrm{N}$ vibrations and $\mathrm{N}-\mathrm{N}$ stretching of aminoguanidinium cations vibrations are observed around 1680 and $1100 \mathrm{~cm}^{-1}$, respectively. The N-H stretchings of aminoguanidinium cations are observed in the range $3420-3300 \mathrm{~cm}^{-1}$.

The infrared spectrum of complex $\mathbf{2}$ is shown in Fig. $2 \mathrm{~b}$. Two sharp and strong bands observed at 1510 and $1430 \mathrm{~cm}^{-1}$ are attributed to the asymmetric and symmetric stretching of carboxylate ions. The $(\Delta v)$ separation $80 \mathrm{~cm}^{-1}$ clearly indicate the bidentate chelation of trichloroacetate ions in this complex. The N-N stretching for hydrazinium cation vibrations is observed at $960 \mathrm{~cm}^{-1}$ which is accordance with the ionic nature of this cation. The asymmetric and symmetric stretchings of $\mathrm{O}=\mathrm{U}=\mathrm{O}$ are seen in the region 920 and $860 \mathrm{~cm}^{-1}$, respectively. The N-H stretchings of hydrazinium cations are observed in the range $3470-3350 \mathrm{~cm}^{-1}$.

Thermal analysis: In case of aminoguanidinium uranyl trichloroacetate from the thermal traces (Fig. 3a), the first step is exothermic and a strong exotherm is observed at $210{ }^{\circ} \mathrm{C}$. The degradation takes place in the temperature range 230 $170^{\circ} \mathrm{C}$ to give uranyl trichloro acetate as an intermediate. The weight loss observed is $12 \%$ which is very close to the calculated value $(11.6 \%)$. Further decomposition takes place in the temperature range $250-600{ }^{\circ} \mathrm{C}$ to yield $\mathrm{U}_{3} \mathrm{O}_{8}$ as the final residue with $22 \%$ weight loss (calcd. $21.63 \%$ ). The DTA shows two weak exotherms.

The thermal traces of complex 2 also shows (Fig. 3b) two step decomposition which is similar to the complex $\mathbf{1}$. Two exotherms are observed for the two steps in DTA at 190 and $380{ }^{\circ} \mathrm{C}$. The same intermediate as in complex $\mathbf{1}$ i.e. uranyl trichloroacetate is formed, which further gives $\mathrm{U}_{3} \mathrm{O}_{8}$ as the final residue. The weight losses observed are 5.5 and $45 \%$, respectively which are in accordance with calculated values (5.2 and $44.87 \%$ ).

Structural description of $\mathrm{H}_{2}(\mathrm{HAgun})_{2}\left[\mathrm{UO}_{2}\left(\mathrm{Cl}_{3} \mathrm{COO}\right)_{5}\right]$ (NO3) (1): The ORTEP of complex $\mathbf{1}$ is shown in Fig 4. The uranyl ion is surrounded by five trichloroacetate ions resulting in the pentagonal bipyramidal geometry around uranium. In the case of simple acetate and propionate complexes, the carboxylate ions coordinate in a bidentate chelating fashion and uranium shows hexagonal bipyramidal structure (eight coordination). However in present case, trichloroacetate ions show monodentate behaviour which is quite expected due to the steric reasons.

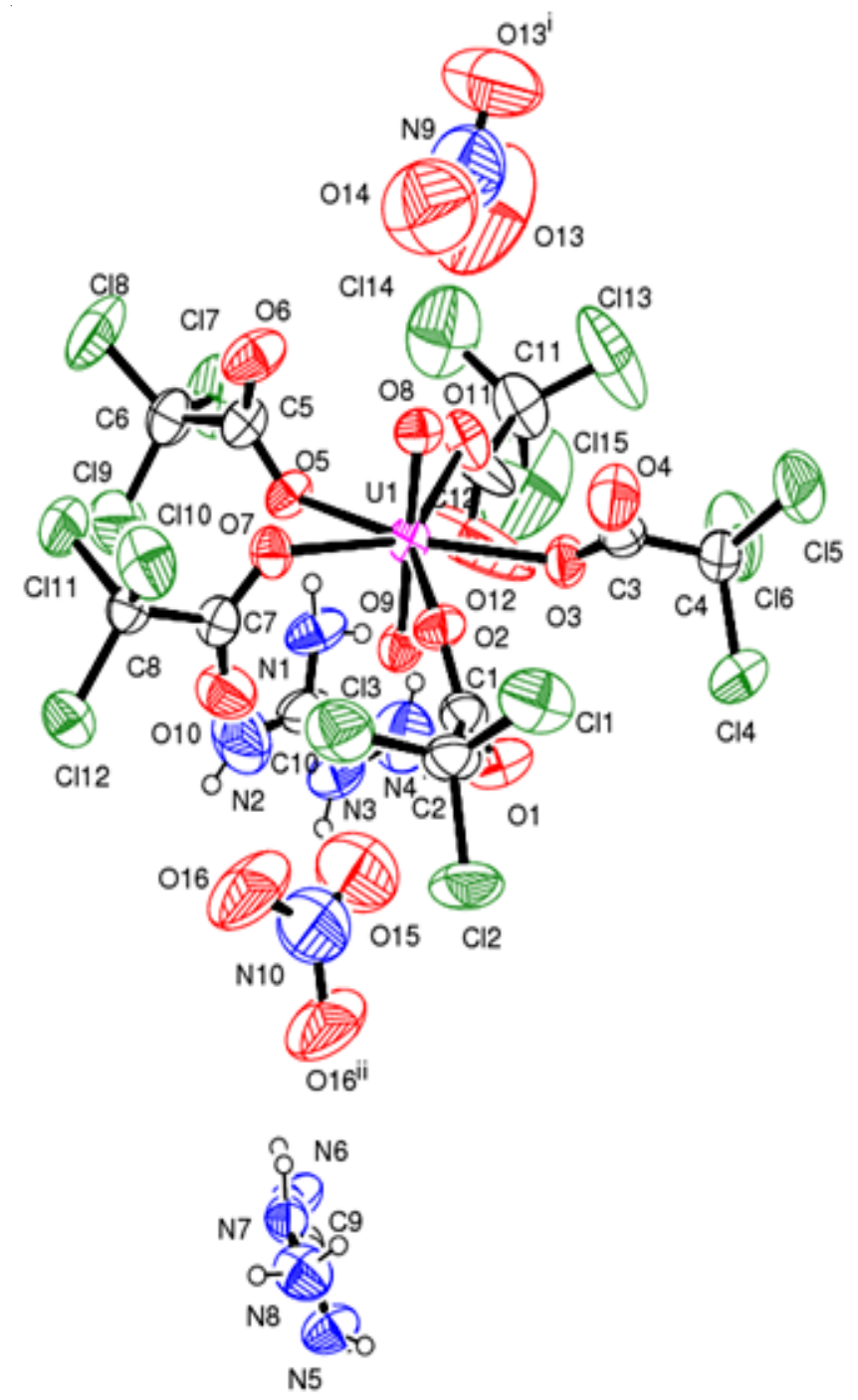

Fig. 4. ORTEP of $\mathrm{H}_{2}(\mathrm{HAgun})_{2}\left[\mathrm{UO}_{2}\left(\mathrm{Cl}_{3} \mathrm{COO}\right)_{5}\right]\left(\mathrm{NO}_{3}\right)$

The average bond length of uranium to carboxylate oxygen is $2.412 \AA$. The uranyl group has linear geometry with an average U-O distance $1.761 \AA$ and O-U-O angle of $179.1(2)^{\circ}$ which are within the range of values observed in the case of several uranyl complexes [19]. The crystal data of the complex are summarized in Table-1. Some important bond lengths and bond angles are given in Table-2. 


\begin{tabular}{|c|c|}
\hline \multicolumn{2}{|c|}{$\begin{array}{c}\text { TABLE-1 } \\
\text { CRYSTAL DATA AND STRUCTURE REFINEMENT } \\
\text { FOR } \mathrm{H}_{2}(\mathrm{HAgun})_{2}\left[\mathrm{UO}_{2}\left(\mathrm{Cl}_{3} \mathrm{COO}\right)_{5}\right]\left(\mathrm{NO}_{3}\right)\end{array}$} \\
\hline CCDC No. & 1818750 \\
\hline Empirical formula & $\mathrm{C}_{12} \mathrm{H}_{14} \mathrm{~N}_{9} \mathrm{O}_{15} \mathrm{UCl}_{155}$ \\
\hline Formula weight & 1294.10 \\
\hline Temperature & $296(2) \mathrm{K}$ \\
\hline Wavelength & $0.71073 \AA$ \\
\hline Crystal system & Monoclinic \\
\hline Space group & $\mathrm{C} 2 / \mathrm{c}$ \\
\hline Unit cell dimensions & $\mathrm{a}=17.7088(4) \AA, \alpha=90^{\circ}$ \\
\hline & $\mathrm{b}=27.1370(6) \AA, \beta=110.364(10)^{\circ}$ \\
\hline & $c=19.1662(4) \AA, \gamma=90^{\circ}$ \\
\hline Volume & $8634.9(3) \AA^{3}$ \\
\hline $\mathrm{Z}$ & 8 \\
\hline Density (calculated) & $1.991 \mathrm{~g} / \mathrm{cm}^{3}$ \\
\hline Absorption coefficient & $4.751 \mathrm{~mm}^{-1}$ \\
\hline $\mathrm{F}(000)$ & 4928 \\
\hline Crystal size & $0.150 \mathrm{~mm} \times 0.100 \mathrm{~mm} \times 0.050 \mathrm{~mm}$ \\
\hline Theta range for data collection & 2.267 to $24.999^{\circ}$ \\
\hline Index ranges & $\begin{array}{l}-21<=\mathrm{h}<=21,-32<=\mathrm{k}<=32, \\
-22<=1<=22\end{array}$ \\
\hline Reflections collected & 70982 \\
\hline Independent reflections & $7603[\mathrm{R}$ (int) $=0.0574]$ \\
\hline Completeness to $\theta=25.242^{\circ}$ & $99.9 \%$ \\
\hline Absorption correction & Semi-empirical from equivalents \\
\hline Max. and min. transmission & 0.7456 and 0.6414 \\
\hline Refinement method & Full-matrix least-squares on $\mathrm{F}^{2}$ \\
\hline Data / restraints / parameters & $7603 / 0 / 527$ \\
\hline Goodness-of-fit on $\mathrm{F}^{2}$ & 1.027 \\
\hline Final $R$ indices $[\mathrm{I}>2 \sigma(\mathrm{I})]$ & $\mathrm{R} 1=0.0468, \mathrm{wR} 2=0.1091$ \\
\hline $\mathrm{R}$ indices (all data) & $\mathrm{R} 1=0.0766, \mathrm{wR} 2=0.1292$ \\
\hline Extinction coefficient & $\mathrm{n} / \mathrm{a}$ \\
\hline Largest diff. peak and hole & 1.722 and -1.214 e. $\AA^{-3}$ \\
\hline
\end{tabular}

TABLE-2

SELECTED BOND LENGTHS $(\AA)$ AND ANGLES $\left(^{\circ}\right)$ FOR $\mathrm{H}_{2}$ (HAgun $)_{2}\left[\mathrm{UO}_{2}\left(\mathrm{Cl}_{3} \mathrm{COO}\right)_{5}\right]\left(\mathrm{NO}_{3}\right)$

\begin{tabular}{cc|cc}
\hline \multicolumn{2}{c|}{ Bong length $(\AA)$} & \multicolumn{2}{c}{ Bong angles $\left(^{\circ}\right)$} \\
\hline U1-O2 & $2.357(5)$ & O8-U1-O9 & $179.1(2)$ \\
U1-O3 & $2.394(6)$ & O8-U1-O2 & $91.2(2)$ \\
U1-O5 & $2.419(5)$ & O9-U1-O2 & $88.1(2)$ \\
U1-O7 & $2.434(5)$ & O8-U1-O11 & $78.9(4)$ \\
U1-O8 & $1.759(5)$ & O9-U1-O11 & $101.4(4)$ \\
U1-O9 & $1.763(5)$ & O2-U1-O11 & $146.7(4)$ \\
U1-O11 & $2.459(19)$ & O3-U1-O11 & $73.9(4)$ \\
N3-N4 & $1.488(13)$ & O5-U1-O11 & $72.7(4)$ \\
N7-N8 & $1.400(14)$ & O7-U1-O11 & $136.9(4)$ \\
& & O8-U1-O3 & $91.3(2)$ \\
& & O9-U1-O3 & $88.0(2)$ \\
& & O2-U1-O3 & $74.6(2)$ \\
& & O8-U1-O5 & $96.2(2)$ \\
& & O9-U1-O5 & $84.6(2)$ \\
& & O2-U1-O5 & $140.5(2)$ \\
& & O3-U1-O5 & $143.5(2)$ \\
& & O8-U1-O7 & $82.7(2)$ \\
& & O9-U1-O7 & $97.6(2)$ \\
& & O2-U1-O7 & $71.5(2)$ \\
& & O3-U1-O7 & $145.5(2)$ \\
& & O5-U1-O7 & $71.2(19)$ \\
& & C10-N2-H2B & $118(3)$ \\
& & C1O-N2-H2A & $119(3)$ \\
& & O14-N9-O13 & $124.9(15)$ \\
\hline & & &
\end{tabular}

Symmetry transformation used to generate equivalent atoms:

$\# 1-\mathrm{x}+2, \mathrm{y},-\mathrm{z}+3 / 2 \# 2-\mathrm{x}+1, \mathrm{y},-\mathrm{z}+3 / 2$
Two aminoguanidinium cations are present as ionic species and not coordinated to metal ion. This is also attributed to the bulkiness of these ions. Furthermore, two nitrate ions are also present outside the coordination sphere in the asymmetric unit with half occupancy due to the thermal disorder. Though we expect two $\mathrm{H}^{+}$ions to be present in the crystal lattice due to their small size we were not able to locate them, similar cases were previously reported in the literature [20,21]. The aminoguanidinium cations are almost planar and have normal bond lengths $1.400 \AA$.

The close packing diagram reveals that unit cell consists of eight molecules. The N-H---O and N-H---Cl intramolecular hydrogen bonding is observed which stabilizes the crystal system. Packing diagram of complex $\mathbf{1}$ along a-axis and c-axis are given in Fig. 5 and 6, respectively. The N-H---O has a zigzag arrangement (along the c-axis) with the angle $117.5^{\circ}$ and $\mathrm{N}-\mathrm{H}---\mathrm{Cl}$ has parallel chain (along the a-axis) with the angle $122.0^{\circ}$. The hydrogen bond distance and angles are given in Table-3.

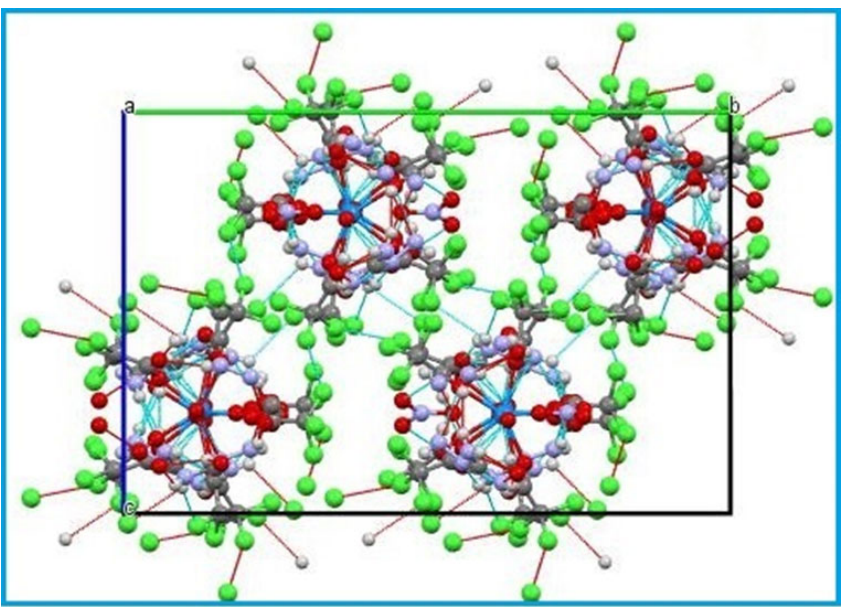

Fig. 5. Hydrogen bonding patterns in the crystal lattice along the a-axis

\begin{tabular}{|c|c|c|c|c|}
\hline \multicolumn{5}{|c|}{$\begin{array}{c}\text { TABLE-3 } \\
\left.\text { HYDROGEN BONDING INTERACTIONS [A AND }{ }^{\circ}\right] \\
\text { FOR } \mathrm{H}_{2}(\mathrm{HAgun})_{2}\left[\mathrm{UO}_{2}\left(\mathrm{Cl}_{3} \mathrm{COO}\right)_{5}\right]\left(\mathrm{NO}_{3}\right)\end{array}$} \\
\hline $\mathrm{D}-\mathrm{H} \cdots \mathrm{A}$ & $\mathrm{d}(\mathrm{D}-\mathrm{H})$ & $\mathrm{d}(\mathrm{H} \cdots \mathrm{A})$ & $\mathrm{d}(\mathrm{D} \cdots \mathrm{A})$ & $\angle(\mathrm{DHA})$ \\
\hline N1-H1A ‥Cl(7) & 0.86 & 2.87 & $3.400(9)$ & 122.0 \\
\hline N1-H1A ‥O(12) & 0.86 & 2.28 & $2.79(3)$ & 117.5 \\
\hline $\mathrm{N} 1-\mathrm{H} 1 \mathrm{~B} \cdots \mathrm{O}(5)$ & 0.86 & 2.24 & $3.009(9)$ & 149.1 \\
\hline $\mathrm{N} 2-\mathrm{H} 2 \mathrm{~B} \cdots \mathrm{Cl}(1)$ & $0.87(2)$ & $2.94(5)$ & $3.398(12)$ & $115(4)$ \\
\hline $\mathrm{N} 2-\mathrm{H} 2 \mathrm{~B} \cdots \mathrm{Cl}(9)$ & 0.87 & 2.91(4) & 3.719 & $157(6)$ \\
\hline $\mathrm{N} 2-\mathrm{H} 2 \mathrm{~A} \cdots \mathrm{O}(1)$ & & $2.47(8)$ & 3.109 & $132(10)$ \\
\hline $\mathrm{N} 3-\mathrm{H} 3 \cdots \mathrm{O}$ & & $2.29(4)$ & 3.0 & \\
\hline N3-H3 ‥ (3) & 2) & $2.59(5)$ & $3.118(10)$ & $121(5)$ \\
\hline 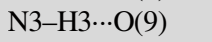 & $0.85(2)$ & $2.54(10)$ & $3.056(11)$ & $120(9)$ \\
\hline $\mathrm{N} 4-\mathrm{H} 4 \mathrm{~B} \cdots \mathrm{O}(12)$ & 0.86 & 2.09 & $2.77(4)$ & 136.4 \\
\hline $\mathrm{N} 4-\mathrm{H} 4 \mathrm{~B} \cdots \mathrm{O}(11)$ & 0.86 & 2.62 & $3.37(2)$ & 146.4 \\
\hline N5-H5A ‥ & $0.84(2)$ & $2.18(5)$ & $2.932(13)$ & $148(8)$ \\
\hline $\mathrm{N} 5-\mathrm{H} 5 \mathrm{~B} \cdots \mathrm{N}(8)$ & 0.85 & 2.70 & $3.449(17)$ & $148(11)$ \\
\hline N6-H6A $\cdots \mathrm{O}(6)$ & & 2.13 & $2.887(11)$ & 147.4 \\
\hline N6-H6B $\cdots O(4)$ & & 2.14 & $2.911(11)$ & 148.4 \\
\hline $\mathrm{N} 7-\mathrm{H} 7 \cdots \mathrm{O}(2)$ & $0.85(2)$ & $2.52(8)$ & $3.144(9)$ & $131(8)$ \\
\hline N7-H7 ..O (4) & $0.85(2)$ & $2.23(6)$ & $2.975(12)$ & $146(9)$ \\
\hline N8-H8A $\cdots \mathrm{Cl}(3)$ & $0.85(2)$ & $2.97(8)$ & $3.522(13)$ & $124(7)$ \\
\hline
\end{tabular}

Symmetry transformation used to generate equivalent atoms: $\# 1-\mathrm{x}+2, \mathrm{y},-\mathrm{z}+3 / 2 ; \# 2-\mathrm{x}+1, \mathrm{y},-\mathrm{z}+3 / 2 ; \# 3-\mathrm{x}+3 / 2,-\mathrm{y}+3 / 2,-\mathrm{z}+2 ; \# 4 \mathrm{x}-1, \mathrm{y}, \mathrm{z}$; \#5 $\mathrm{x},-\mathrm{y}+1, \mathrm{z}+1 / 2 ; \# 6-\mathrm{x}, \mathrm{y},-\mathrm{z}+3 / 2$ 


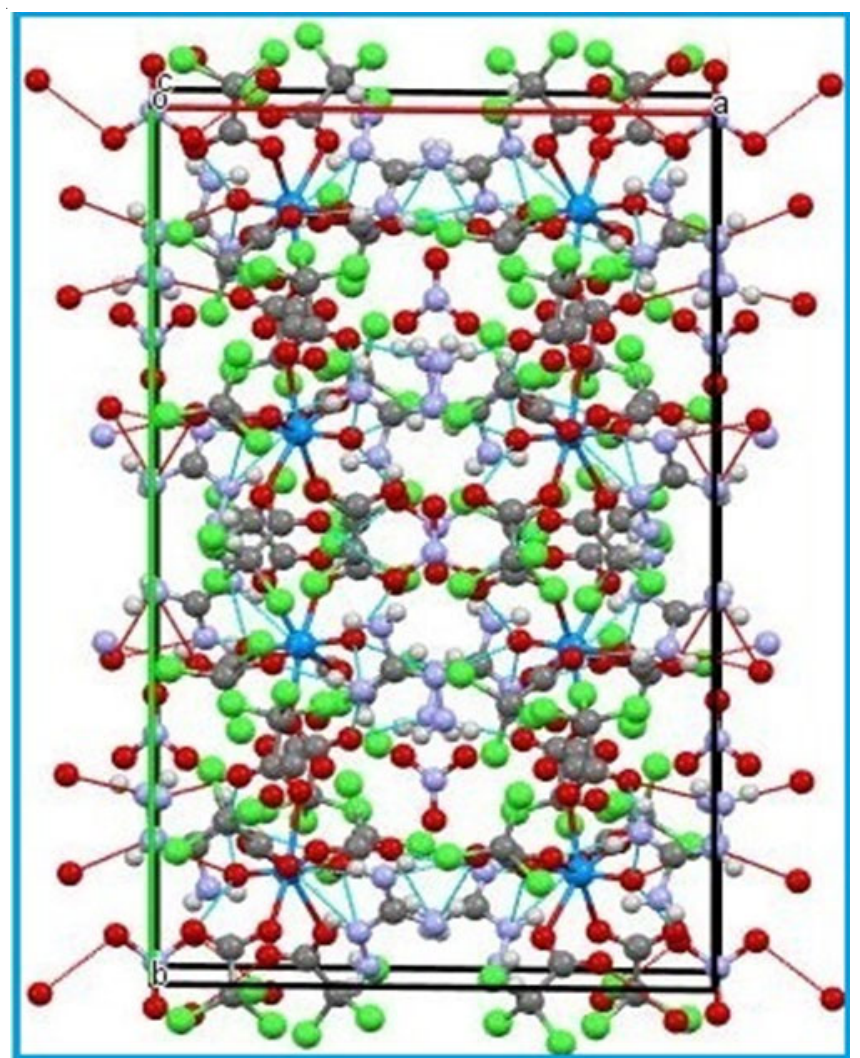

Fig. 6. Hydrogen bonding patterns in the crystal lattice along the c-axis

The geometry of complex $\mathbf{2}$ is expected to be hexagonal bipyramidal with three bidentate chloroacetate ion around uranyl cation which is similar to that of hydrazinium uranyl acetate complex for which the structure has been already determined [22].

Powder X-ray diffraction: Both the complex precursors on complete pyrolysis yielded the same uranium oxide as the final residue. These oxides were confirmed by analytical studies and powder X-ray diffraction (PXRD) technique. The X-ray powder diffraction pattern of oxide prepared from complex 1 is given in Fig. 7 as represented model. The obtained peaks are well indexed with standard $\mathrm{U}_{3} \mathrm{O}_{8}$ pattern (JCPDS file no. 31-1425).

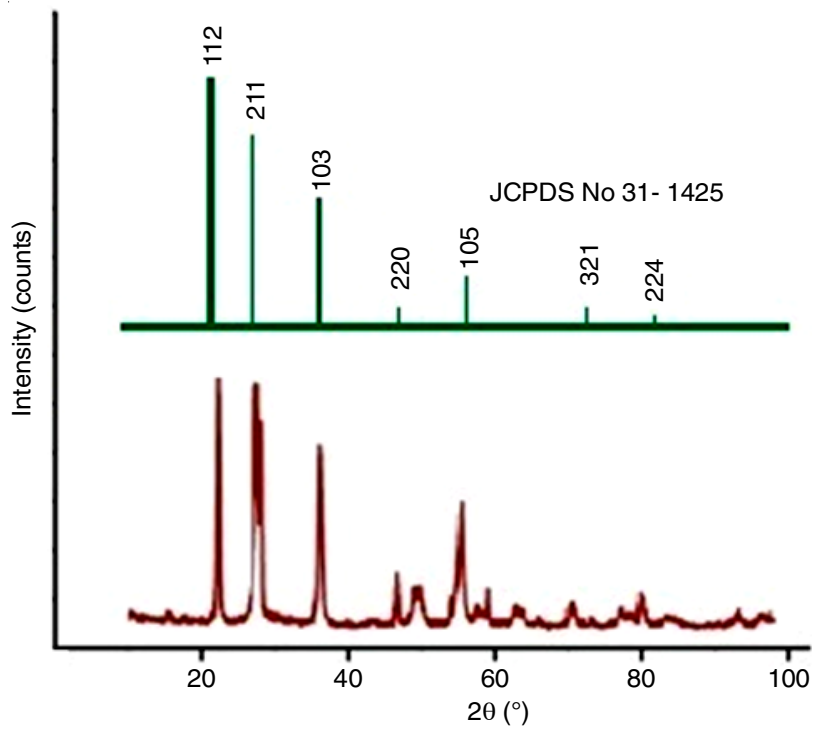

Fig. 7. Powder $\mathrm{X}$-ray diffraction of $\mathrm{U}_{3} \mathrm{O}_{8}$ and the standard

Scanning electron microscopy (SEM): The structural morphology of oxides prepared from complex precursors are examined by their SEM morphologies. These oxides show lot of voids and cracks indicating the large quantity of gases evolved during the decomposition. The different magnification of SEM photographs of oxide prepared from acetate complex is shown in Fig. 8.
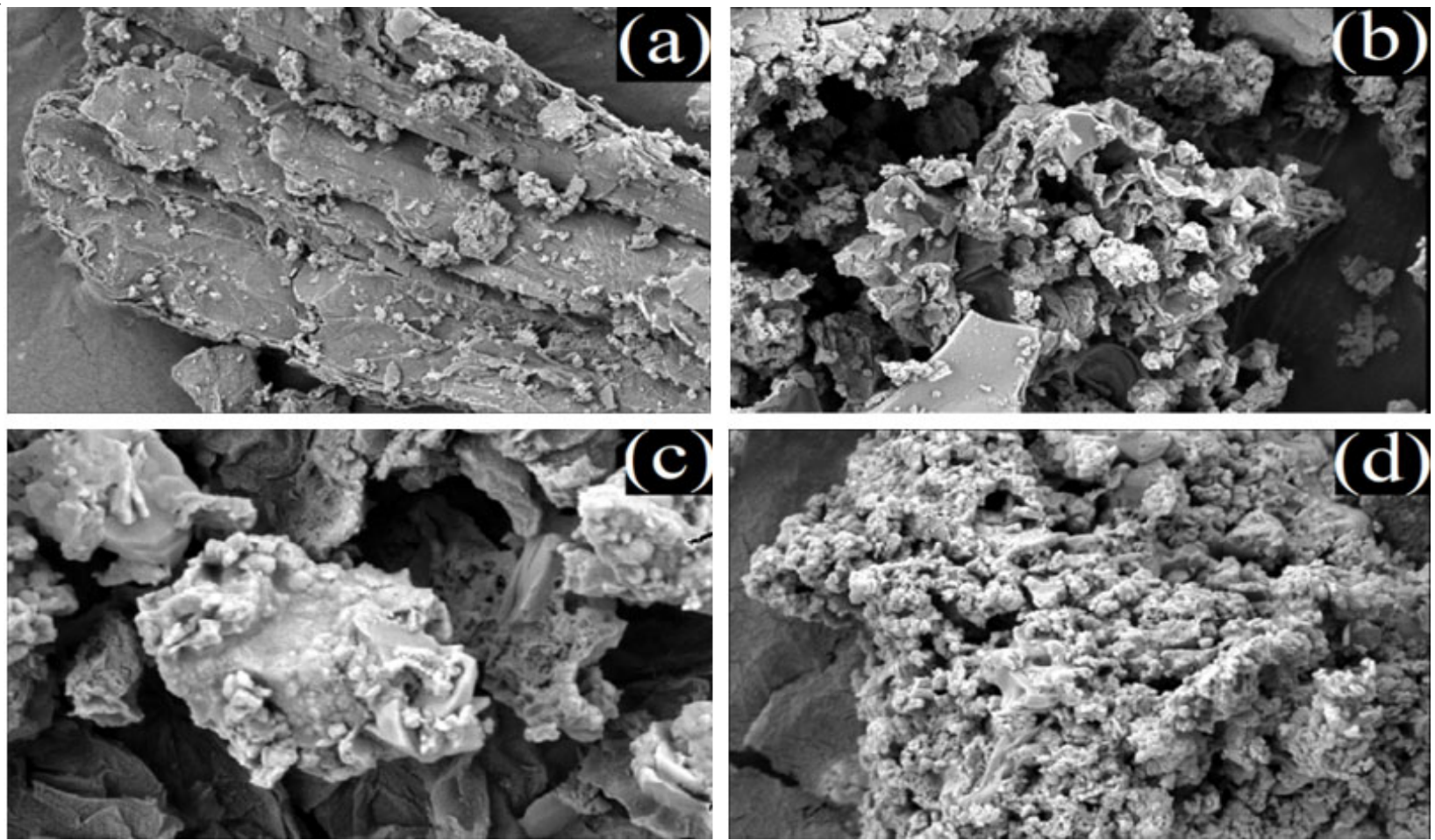

Fig. 8. Scanning electron microscopy images of $\mathrm{U}_{3} \mathrm{O}_{8}$ (a) $2 \mu \mathrm{m}$ mag $=5.00 \mathrm{kx}$ (b) $2 \mu \mathrm{m}$ mag $=10.00 \mathrm{kx}$ (c) $200 \mathrm{~nm}$ (d) $1 \mu \mathrm{m}$ 


\section{ACKNOWLEDGEMENTS}

One of the authors, T.M. Ahamed Hussain is grateful to UGC, New Delhi, India for RGNFD fellowship (Ref. No. F./ 2016-17/RGNFD-2016-17-TAM-2463).

\section{CONFLICT OF INTEREST}

The authors declare that there is no conflict of interests regarding the publication of this article.

\section{REFERENCES}

1. M.S. Bharara, K. Strawbridge, J.Z. Vilsek, T.H. Bray and A.E.V. Gorden, J. Inorg. Chem., 46, 8309 (2007); https://doi.org/10.1021/ic7010315.

2. Y.-R. Guo, Q. Wu, S.O. Odoh, G. Schreckenbach and Q.-J. Pan, J. Inorg. Chem., 52, 9143 (2013); https://doi.org/10.1021/ic401440w.

3. K.R.D. Johnson and P.G. Hayes, Chem. Soc. Rev., 42, 1947 (2013); https://doi.org/10.1039/C2CS35356C.

4. H.T. Evans, Science, 141, 154 (1963); https://doi.org/10.1126/science.141.3576.154.

5. R.G. Denning, J. Phys. Chem. A, 111, 4125 (2007); https://doi.org/10.1021/jp071061n.

6. P.L. Arnold, A.-F. Pecharman, E. Hollis, A. Yahia, L. Maron, S. Parsons and J.B. Love, Nat. Chem., 2, 1056 (2010); https://doi.org/10.1038/nchem.904.

7. R.J. Baker, J. Eur. Chem., 18, 16258 (2012); https://doi.org/10.1002/chem.201203085.

8. J.L. Sessler, P.J. Melfi and G.D. Pantos, Coord. Chem. Rev., 250, 816 (2006);

https://doi.org/10.1016/j.ccr.2005.10.007.
9. C.K. Prier, D.A. Rankic and D.W.C. MacMillan, Chem. Rev., 113, 5322 (2013); https://doi.org/10.1021/cr300503r

10. L.S. Natrajan, Coord. Chem. Rev., 256, 1583 (2012); https://doi.org/10.1016/j.ccr.2012.03.029.

11. S.J. Jennifer and P.T. Muthiah, Inorg. Chim. Acta, 416, 69 (2014); https://doi.org/10.1016/j.ica.2014.03.014.

12. H. Sopo, J. Sviili, A. Valkonen and R. Sillanpää, Polyhedron, 25, 1223 (2006); https://doi.org/10.1016/j.poly.2005.08.044.

13. B. Subramani, B.N. Sivasankar and R.W. Sugumar, Int. J. Chem., 3, 27 (2014).

14. L. Erdey and I. Buzaz, Gravimetric Analysis (Part II), Pergamon: London (1965).

15. A.I. Vogels, A Text Book of Quantitative Inorganic Analysis, Longmans: London, edn 3 (1962)

16. C.K. Johnson, ORTEP ORNL-3794, Oak Ridge National Laboratory, Tennessee (1976)

17. G.M. Sheldrick, SHELXL-2014 Programs for Crystal Structure Determination, University of Cambridge: England (1977).

18. S.P. Mcglynn and J.K. Smith, J. Mol. Spectrosc., 6, 164 (1961); https://doi.org/10.1016/0022-2852(61)90237-5.

19. M. Aberg, Acta Chim. Scand., 23, 791 (1969); https://doi.org/10.3891/acta.chem.scand.23-0791.

20. C.R. Ross II, M.R. Bauer, R.M. Nielson and S.C. Abrahams, Acta Cryst., B58, 841 (2002); https://doi.org/10.1107/S0108768102012624.

21. G.V. Romanenko, Z.A. Savelyeva, N.V. Podberezskaya, V.I. Alekseev and S.V. Larionov, J. Struct. Chem., 35, 317 (1994); https://doi.org/10.1007/BF02578283.

22. K. Kuppusamy, B.N. Sivasankar and S. Govindarajan, Thermochim. Acta, 274, 139 (1996); https://doi.org/10.1016/0040-6031(95)02538-3. 